\title{
Aplikasi "Si Tubo" untuk Mendeteksi Dini Gejala Tuberkulosis pada Anak dengan Metode Backward Chaining
}

Ika Romadoni, Fiby Nur Afiana, Yunita

Universitas Amikom Purwokerto, Indonesia

\section{Article Info}

Article history:

Received, 25 April 2020

Revised, 9 May 2020

Accepted, 28 May 2020

\section{Kata kunci:}

Tuberkulosis

Anak-anak

Backward Chaining

Kekebalan

Si Tubo

\section{Keywords:}

Tuberculosis

Childdrem

Backward Chaining

Immunity

Si Tubo

\begin{abstract}
ABSTRAK
Anak-anak adalah kelompok usia dengan risiko yang tinggi tertular Tuberkulosis karena kekebalan tubuh yang belum berkembang secara sempurna. Tuberkulosis aktif pada anak dapat dicegah atau diketahui sejak dini apabila orang tua mengetahui ciri-ciri dan media penularan Tuberkulosis. Sayangnya informasi tersebut belum menyentuh seluruh aspek masyarakat, kurangnya dokter dan stakeholder yang terlibat untuk mensosialisasikan, mahalnya bisaya konsultasi dan berobat menjadi faktor pendukung. Dengan bantuan teknologi, peneliti berusaha memberikan informasi yang akurat mengenai Tuberkulosis. Penelitian ini merancang dan membangun aplikasi mobile bernama "Si Tubo", dengan metode inferensi Backward Chaining yang dapat membantu para orang tua dan stakeholder yang terlibat untuk mendeteksi dini gejala-gejala penyakit Tuberkulosis pada anak dan mencegah penularan. Basis pengetahuan berdasar pada Peraturan Menteri Kesehatan Republik Indonesia Nomor 67 Tahun 2016 Tentang Penanggulangan Tuberkulosis, beberapa literature dan konsultasi dengan Dokter Anak setempat sebagai si pakar. Namun aplikasi ini hanya mendeteksi dini bukan mendiagnosis bahwa anak terkena Tuberkulosis. Melalui Aplikasi Si Tubo orang tua bisa melakukan langkah pencegahan atau pemeriksaan lebih lanjut ke rumah sakit terkait bila ternyata anak diduga Tuberkulosis aktif.
\end{abstract}

\section{ABSTRACT}

Children are an age group with a high risk of contracting tuberculosis due to immunity that has not fully developed. Active tuberculosis in children can be prevented or known early if parents know the characteristics and media of tuberculosis transmission. Unfortunately, this information has not touched all aspects of society, the lack of doctors and stakeholders involved to socialize, the high cost of consultation and treatment is a supporting factor. With the help of technology, researchers are trying to provide accurate information about tuberculosis. This study designed and built a mobile application called "Si Tubo", with a Backward Chaining inference method that can help parents and stakeholders involved to detect early symptoms of tuberculosis in children and prevent transmission. The knowledge base is based on the Regulation of the Minister of Health of the Republic of Indonesia Number 67 Year 2016 Regarding the Prevention of Tuberculosis, some literature and consultation with the local Pediatrician as the expert. However, this application only detects early, not diagnoses that the child has tuberculosis. Through the Si Tubo Application, parents can take preventative measures or further examinations to the relevant hospital if it turns out the child is suspected to be active tuberculosis.

This is an open access article under the CC BY-SA license.

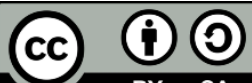

\section{Penulis Korespondensi:}

Ika Romadoni,

Program Studi Sistem Informasi,

Universitas Amikom Purwokerto.

Email: ikarom@amikompurwokerto.ac.id 


\section{PENDAHULUAN}

Perkembangan Tuberkulosis sangat pesat terjadi di Indonesia bahkan dunia. Jumlah kasus baru Tuberkulosis di Indonesia sebanyak 420.994 kasus pada tahun 2017 (data per 17 Mei 2018) [1]]. Tidak hanya menyerang orang dewasa, namun virus Tuberkulosis juga dapat menyerang anak kapan saja dan dimana saja. Dimana anak adalah kelompok dengan risiko yang tinggi karena kekebalan tumbuh yang belum berkembang secara sempurna [2]. Berdasarkan Survei Prevalensi Tuberkulosis 2013-2014 Kemenkes RI [1] pada gambar 1, anak usia 1-4 tahun jumlahnya lebih tinggi dibandingkan usia 5-44 tahun.

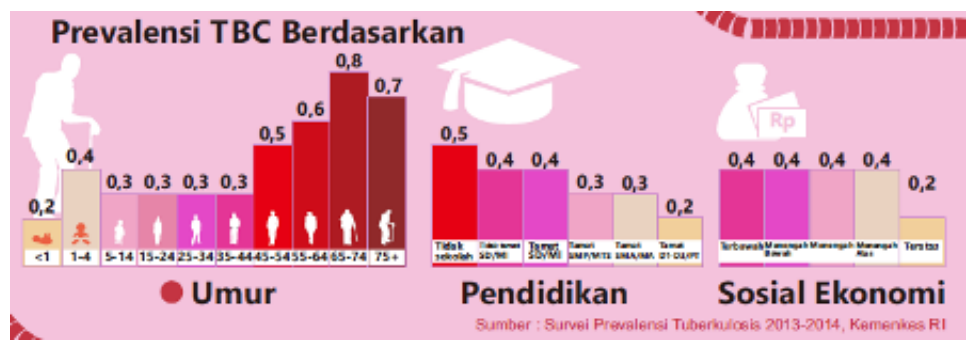

Gambar 1. Survei Prevalensi Tuberkulosis 2013-2014 Kemenkes RI

World Health Organization (WHO) menyatakan tiap tahun terdapat 1,3 juta kasus baru terkait Tuberkulosis anak di dunia [2]. Faktor yang mempengaruhi pesatnya perkembangan virus Tuberkulosis adalah faktor sosial dan geografis dimana kondisi sosial dan geografis menimbulkan variasi kondisi lingkungan rumah, ekonomi, perilaku pencarian pengobatan dan kepercayaan terhadap mitos tertentu [2] , [ㄱ] . Namun Tuberkulosis pada anak biasanya jarang mendapatkan perhatian dan cenderung diabaikan para orang tua, Tuberkulosis yang tidak dideteksi dini dan tidak mendapatkan penanganan yang tepat dapat mengakibatkan penderitaan berkepanjangan bahkan dapat menimbulkan kematian [4]. Diagnosis Tuberkulosis pada anak lebih sulit dibandingkan pada dewasa, karena gejalanya terkadang kurang khas dan anak belum dapat sepenuhnya mengeluarkan dahak untuk diperiksa. Selain itu faktor ekonomi menjadi salah satu penyebab utama telatnya penanganan terhadap penderita serta faktor kelalaian orang tua terhadap ciri-ciri yang ditimbulkan penderita [5]. Untuk mendapatkan diagnosis yang akurat, penderita sebelumnya harus menjalani beberapa pemeriksanaan seperti tes kulit tuberkulin atau tes Mantoux yang memerlukan biaya yang tidak sedikit dan apabila positif menderita Tuberkolosis aktif, penderita wajib mengkonsumsi obat setiap hari selama sembilan bulan berturut-turut. Tuberkulosis aktif pada anak dapat dicegah atau diketahui sejak dini apabila orang tua mengetahui ciri-ciri dan media penularan Tuberkulosis kepada anak. Sayangnya informasi tersebut belum menyentuh seluruh aspek masyarakat, kurangnya dokter dan stakeholder yang terlibat untuk mensosialisasikan, mahalnya biaya konsultasi dan berobat menjadi faktor pendukung. Seperti yang kita lihat pada gambar 1 dari sosial ekonomi yang menempati urutan teratas penderita Tuberkulosis dimulai dari kalangan terbawah hingga menengah. Dimana kalangan terbawah sulit menjangkau segala fasilitas kesehatan karena faktor biaya. Pendidikan juga turut mempengaruhi perilaku dimana angka tidak sekolah menempati urutan teratas.

Dengan bantuan teknologi peneliti berusaha memberikan informasi yang akurat mengenai Tuberkulosis terhadap orang tua dengan sebuah aplikasi mobile yang dapat digunakan dimana saja dan kapan saja. Aplikasi mobile "Si Tubo" dibuat dengan bantuan sistem pakar dimana sistem pakar adalah suatu cabang kecerdasan buatan [6] -[8]. Pengetahuan pakar dituangkan dalam suatu teknologi aplikasi mobile yang dapat digunakan siapa saja dengan mengunduh di play store dengan biaya $\mathrm{Rp} 0,-$. Penelitian ini menggunakan teknik inferensi Backward Chaining dalam pembahasannya. Backward Chaining adalah metode pelacakan kebelakang yang memulai penalarannya dari kesimpulan (goal), dengan mencari sekumpulan hipotesa-hipotesa menuju faktafakta yang mendukung sekumpulan hipotesa-hipotesa tersebut [9]-[111]. Backward Chaining digunakan karena fokus pada tujuan, menghasilkan seraikan pertanyaan yang relevan dan mempunyai diagnosis yang baik.

Dwi [12] mengembangkan sistem pakar diagnosis penyebab penyakit stroke dengan metode backward chaining. Pohon keputusan ditelusuri dengan tehnik breadth-first search dimana node pada gejala penyakit yang ditunjukan oleh penderita akan dihubungkan dengan ars (busur) dengan menelusuri seluruh node yang ada sehingga didapatkan kesimpulan yang diinginkan. Iriani [10] mengembangkan sistem pakar diagnosis penyakit tulang manusia menggunakan metode backward chaining yang Pada penelusuran menggunakan metode Depth First Search yang akan melakukan penelusuran kaidah secara mendalam dari simpul akar bergerak menurun ke tingkat dalam yang berurutan.

Latubessy dan Jazuli [9] mengembangkan sistem pakar untuk mendeteksi tingkat kecanduan game pada anak dengan metode backward chaining. Backward chaining baik digunakan untuk sistem yang memiliki sedikit hipotesis keluaran dan data. Jika fakta-fakta yang diberikan menuntun kepada kesimpulan yang banyak, 
tetapi cara untuk meraih kesimpulan tertentu sedikit, maka akan lebih banyak informasi yang keluar dari pada informasi yang masuk, maka backward chaining lebih banyak digunakan.

\section{METODE PENELITIAN}

Subjek penelitian dalam kasus ini adalah "Si Tubo" sebagai media yang dapat membantu para orang tua mendiagnosis dini gejala Tuberkulosis pada anak. Aplikasi "Si Tubo" terdiri dari beberapa tahap, diantaranya:

\subsection{Tahap Pertama}

Tahap pertama merupakan tahap perencanaan, dimana pada tahap ini dilakukan persiapan, studi literatur dan rumusan masalah.

\subsection{Tahap Kedua}

Tahap kedua yaitu tahap pengumpulan data melalui observasi, wawancara, kuisoner dan dokumentasi serta melakukan pengolahan data yang telah didapatkan.

Pengumpulan data digunakan dalam memperoleh data-data yang dibutuhkan dalam penyusunan penelitian ini. Adapun metode pengumpulan data yang dilakukan adalah:

1. Observasi, ialah pengamatan dengan format atau blangko tertentu untuk penilaian. Dengan mengunjungi salah satu Dokter Anak di Kabupaten Banyumas.

2. Interview/wawancara, dilakukan kepada salah satu Dokter Anak di Kabupaten Banyumas.

3. Studi Kepustakaan dilakukan ketua dan anggota dengan mempelajari literatur, paket modul dan panduan, buku-buku pedoman, buku-buku perpustakaan dan segala kepustakaan lainnya yang dianggap perlu dan mendukung.

4. Dokumentasi, melakukan pengumpulan data yang berupa dokumen-dokumen yang berhubungan dengan Tuberkulosis pada anak.

\subsection{Tahap ketiga yaitu tahap analisis dan pembahasan}

Daftar penyakit dan ciri-ciri berdasarkan Peraturan Menteri Kesehatan Republik Indonesia Nomor 67 Tahun 2016 Tentang Penanggulangan Tuberkulosis [13], beberapa literature dan konsultasi dengan Dokter Anak setempat diperoleh 2 tingkatan Tuberkulosis dan 12 data gejala Tuberkulosis pada anak. Pelaksanaan dimulai dari pengumpulan data penyakit, data ciri-ciri, merancang basis pengetahuan, kaidah produksi, penyusunan pohon keputusan hingga implementasi antarmuka.

\subsection{Tahap Keempat}

Tahap keempat yaitu tahap dokumentasi hasil penelitian yang disusun oleh ketua dan anggota.

\section{HASIL DAN ANALISIS}

\subsection{Analis Sistem}

Aplikasi Si Tubo menggunakan metode backward chaining untuk memperoleh kesimpulan bagaimana mendeteksi dini gejala Tuberkulosis pada anak berdasarkan ciri-ciri yang terlihat. Backward chaining melakukan pengecekan ke belakang yang memulai penalarannya dari kesimpulan gejala Tuberkulosis dengan 2 tahapan tahap paparan Tuberkulosis dan Tuberkulosis aktif yang terdapat pada aplikasi.

Gejala Tuberkulosis harus segera diketahui karena proses pengobatan yang berlangsung relatif lama dan perlu pengecekan yang lebih lanjut karena aplikasi ini hanya mendeteksi dini bukan langsung mendiagnosis bahwa anak terkena Tuberkulosis. Dalam penelitian data-data yang dikumpulkan berdasar dari Peraturan Menteri Kesehatan Republik Indonesia Nomor 67 Tahun 2016 Tentang Penanggulangan Tuberkulosis [13], beberapa literature dan konsultasi dengan Dokter Anak setempat diperoleh 2 tingkatan Tuberkulosis dan 12 data gejala Tuberkulosis pada anak.

\subsection{Data Penyakit}

Berikut table 1 merupakan tabel yang menunjukkan tingkatan/data penyakit Tuberkulosis yang diperoleh untuk diterapkan dalam penelitian yang akan dilakukan. 
Tabel 1. Data Penyakit

\begin{tabular}{cc}
\hline Kode Penyakit & Nama Penyakit \\
\hline TB1 & Tahap Paparan Tuberkulosis \\
TB2 & Tuberkulosis Aktif \\
\hline
\end{tabular}

\subsection{Data Ciri-ciri}

Berdasarkan data penyakit yang ada, diperoleh data ciri-ciri yang dapat dilihat pada tabel 2.

Tabel 2. Daftar Nama Ciri-Ciri

\begin{tabular}{cl}
\hline Kode Gejala & \multicolumn{1}{c}{ Nama Gejala } \\
\hline B01 & $\begin{array}{l}\text { Serumah dengan penderita Tuberkulosis positif } \\
\text { Terdapat reaksi kemerahan cepat setelah penyuntikan Imunisasi BCG } \\
\text { B02 }\end{array}$ \\
(dalam 3-7 hari) \\
B03 & Berat badan turun 3 bulan berturut-turut \\
B04 & Demam lama/berulang, tanpa sebab yang jelas \\
B05 & Batuk lama lebih dari 30 hari, dengan tanda cairan didada dan nyeri dada \\
B06 & Batuk darah \\
B07 & Diare berulang \\
B08 & Tubuh terasa lemah \\
B09 & Sesak nafas \\
B10 & Berkeringat di malam hari \\
B11 & Pembengkakan kelenjer getah bening/Terdapat benjolan pada leher yang \\
B12 & bisa diraba \\
\hline
\end{tabular}

\subsection{Merancang Basis Pengetahuan Solusi Pengendalian}

Berdasarkan pengetahuan pakar dalam hal ini Dokter Anak, untuk mengatasi permasalahan mengenai Tuberkulosis pada anak dapat dilihat pada tabel 3.

Tabel 3. Basis Pengetahuan Solusi Tuberkulosis pada anak

\begin{tabular}{|c|c|c|}
\hline ID & Nama Penyakit & Solusi \\
\hline TB1 & $\begin{array}{c}\text { Tahap Paparan } \\
\text { Tuberkulosis }\end{array}$ & $\begin{array}{l}\text { IF Diduga Tahap Paparan Tuberkulosis } \\
\text { THEN Pola hidup sehat, hindari interaksi } \\
\text { dengan penderita Tuberkulosis aktif, } \\
\text { Segera hubungi dokter terdekat untuk } \\
\text { penanganan lebih lanjut. }\end{array}$ \\
\hline TB2 & Tuberkulosis Aktif & $\begin{array}{l}\text { IF Diduga Tuberkulosis Aktif THEN } \\
\text { Segera hubungi dokter terdekat untuk } \\
\text { penanganan dan pemeriksaan lebih lanjut. }\end{array}$ \\
\hline
\end{tabular}

\subsection{Kaidah Produksi}

Kaidah produksi dituliskan dalam bentuk IF-THEN. Dengan referensi data dari Peraturan Menteri Kesehatan Republik Indonesia Nomor 67 Tahun 2016 Tentang Penanggulangan Tuberkulosis [13], beberapa literature dan konsultasi dengan Dokter Anak setempat. Kaidah produksi disusun dengan merujuk pada buku dan penelitian sebelumnya, Berikut adalah kaidah produksi penelitian yang digunakan []], [12].

\subsubsection{Tahap Paparan Tuberkulosis}

IF Diduga Tahap Paparan Tuberkulosis (TB1) THEN Serumah dengan penderita Tuberkulosis positif (B01) AND Terdapat reaksi kemerahan cepat setelah penyuntikan Imunisasi BCG (dalam 3-7 hari) (B02). 


\subsubsection{Tuberkulosis Aktif}

IF Diduga Tuberkulosis Aktif (TB2) THEN Berat badan turun 3 bulan berturut-turut (B03) AND Nafsu makan tidak ada (Anorexia) (B04) AND Demam lama/berulang, tanpa sebab yang jelas (B05) $A N D$ Batuk lama lebih dari 30 hari, dengan tanda cairan didada dan nyeri dada (B06) AND Batuk darah (B07) AND Diare berulang(B08) $A N D$ Tubuh terasa lemah (B09) $A N D$ Sesak nafas (B10) $A N D$ Berkeringat di malam hari (B11) $A N D$ Pembengkakan kelenjer getah bening/Terdapat benjolan pada leher yang bisa diraba (B12).

\subsection{Pohon Keputusan}

Seluruh basis pengetahuan dengan aturan (kaidah produksi) telah lengkap atau berada pada level yang akurat, maka basis pengetahuan dan kaidah produksi siap diaplikasikan menuju pembuatan mesin infrensi. Pengetahuan di dalam basis pengetahuan dan kaidah produksi menjadi dasar dari mesin inferensi. Pada penelitian ini, pembuatan mesin inferensi mengacu pada metode inferensi backward chaining Pohon Keputusan dibuat untuk menghasilkan kaidah yang efisien dalam beberapa tahapan yang harus ditempuh [11], [12], [14]. Pohon keputusan dalam penelitian ini pada gambar 3.

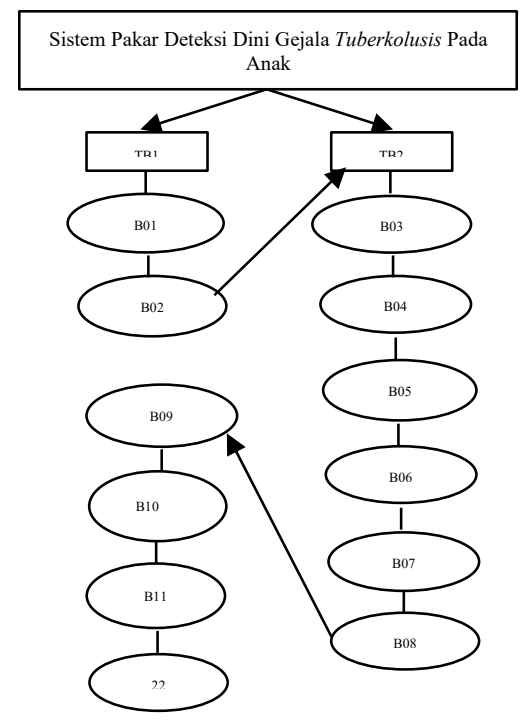

Gambar 3. Pohon Keputusan

\subsection{Implementasi Antarmuka} Si Tubo

Tujuan dari implementasi antarmuka adalah untuk menggambarkan bagaimana cara penggunaan aplikasi

\subsubsection{Form Register}

Form Register ditujukan bagi orang tua anak pada gambar 4. Orang tua mengisi no telpon beserta password untuk melakukan proses pendaftaran. Langkah selanjutnya dapat melakukan verifikasi melalui no telpon yang telah diinputkan. Verifikasi dilakukan melalui no telpon tidak melalui email karena tidak semua orang tua memiliki email yang aktif digunakan.

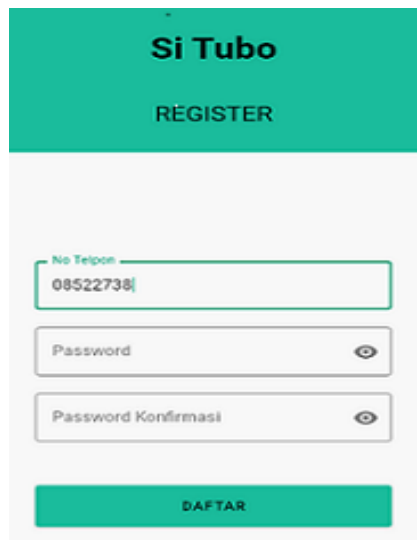

Gambar 4. Form Register 
Setelah melakukan register dan verifikasi orang tua dapat login dengan no telpon dan password yang telah didaftarkan pada gambar 5 .

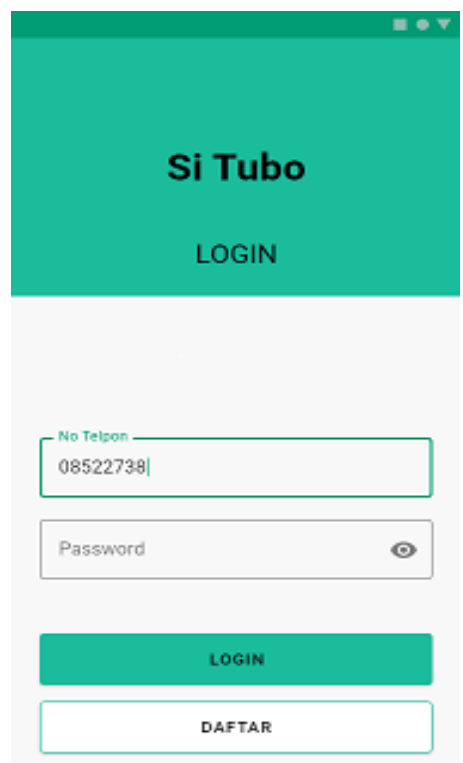

Gambar 5. Login User

\subsubsection{Form Pengguna}

Setelah melakukan login, pengguna akan ditampilkan ke halaman utama pada gambar 6 . Orang tua bisa menginputkan lebih dari satu data anak dan bisa melakukan pengecekan lebih lanjut. Terdapat juga informasi/artikel mengenai Tuberkulosis pada anak.

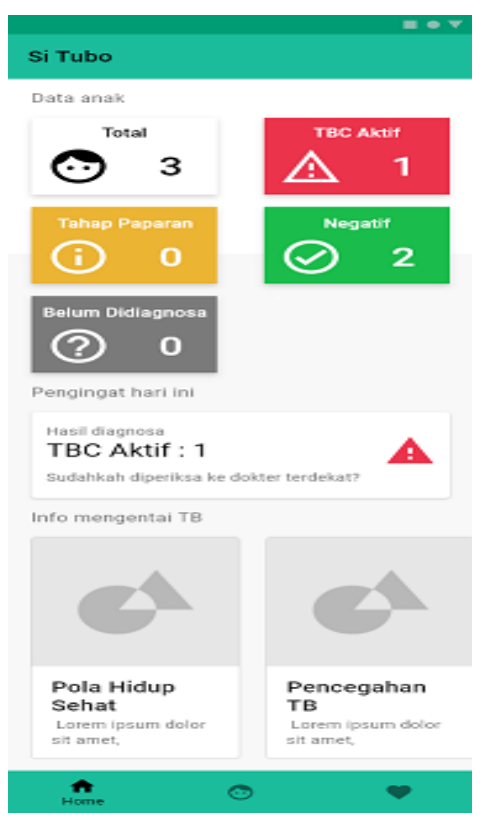

Gambar 6. Home Pengguna

\subsubsection{Form Diagnosis}

Gambar 7 adalah salah satu pertanyaan yang harus dijawab orang tua untuk melihat bagaimana kondisi dari anak. Pertama terdiri dari 2 pertanyaan diawal yang nantinya akan bisa berlanjut hingga total 12 pertanyaan. 


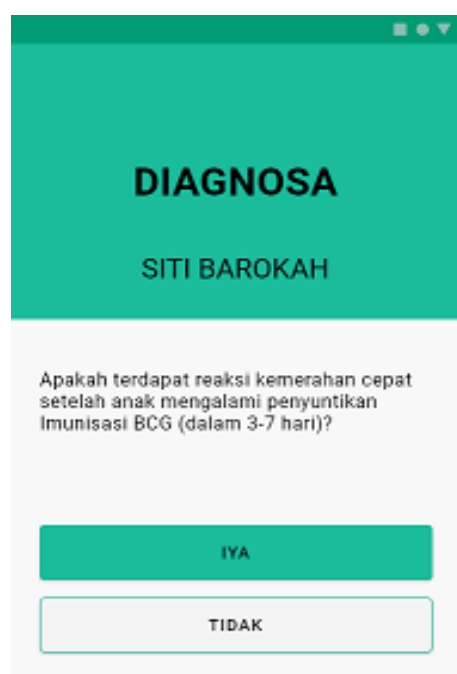

Gambar 7. Form Diagnosis

Setelah mengisi beberapa pertanyaan, orang tua akan mendapatkan kesimpulan. Gambar 8 adalah salah satu contoh hasil dari isian yang orang tua lakukan. Hasilnya anak diduga terpapar dan berisiko untuk terlular Tuberkulosis. Seperti yang dijelaskan pada basis pengetahuan solusi pengendalian diduga terpapar karena berinteraksi langsung dengan Tuberkulosis dewasa yang aktif. Pada tahapan ini diberikan pilihan akan lanjut lagi ke tahapan berikutnya untuk diagnosis lebih lanjut atau stop yang akan diberikan solusi berupa rtikel hidup sehat dan bagaimana pencegahan Tuberkulosis.

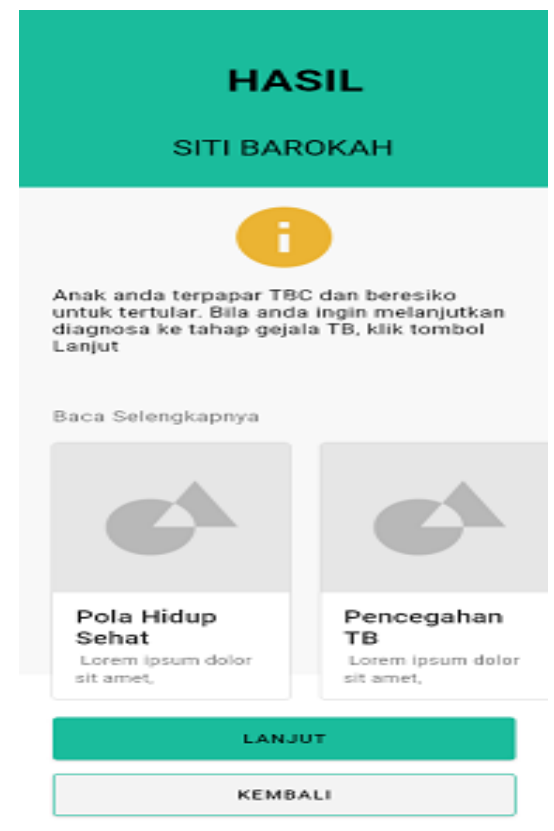

Gambar 8. Hasil Isian

\subsection{Pengujian Validasi}

Untuk melihat sejauh mana kinerja dari sistem pakar khususnya metode backward chaining yang ada untuk memberikan hasil analisa pada diagnosis berdasarkan pada ciri-ciri yang terlihat dinamakan pengujian validasi [7], [15]. Hasil rekomendasi yang didapatkan dari sistem pakar, dicocokan dengan hasil analisa dari pakar (Dokter Anak). Hasil yang didapatkan dari pengujian akurasi sistem pakar ditunjukkan pada tabel 4 : 
Tabel 4. Pengujian Validasi

\begin{tabular}{ccclc}
\hline No & $\begin{array}{c}\text { Diagnosis } \\
\text { Pakar }\end{array}$ & $\begin{array}{c}\text { Diagnosis } \\
\text { Sistem }\end{array}$ & NA & \% \\
\hline 1 & $\begin{array}{c}\text { Tahap Paparan } \\
\text { Tuberkulosis }\end{array}$ & $\begin{array}{c}\text { Tahap Paparan } \\
\text { Tuberkulosis }\end{array}$ & 1 & 100 \\
\hline 2 & $\begin{array}{c}\text { Tuberkulosis } \\
\text { Aktif }\end{array}$ & $\begin{array}{c}\text { Tuberkulosis } \\
\text { Aktif }\end{array}$ & 1 & 100 \\
\hline & & &
\end{tabular}

Dari tabel 4 pengujian akurasi dengan 2 sampel data dari diagnosis dini Tuberkulosis pada anak dan menghasilkan nilai dari akurasi sesuai perhitungan berikut :

$$
\begin{aligned}
& \text { Nilai akurasi }=\frac{\text { Jumlah data akurat }}{\text { Jumlah seluruh data }} \times 100 \% \\
& \text { Nilai Akurasi }=\frac{2}{2} \times 100 \%=100 \%
\end{aligned}
$$

Kesimpulan dari akurasi sistem pakar dengan metode Backward Chaining berdasarkan 2 data tingkatan yang dilakukan adalah 100\% menunjukkan bahwa sistem bakar Aplikasi Si Tubo dapat berfungsi dengan baik.

\section{KESIMPULAN}

Aplikasi Si Tubo dirancang dengan mengacu pada metode inferensi Backward Chaining. Metode Backward Chaining tepat digunakan karena penelitian ini memiliki sedikit hipotesis keluaran dan data. Basis pengetahuan berdasar pada konsultasi dengan Dokter Anak, Peraturan Menteri Kesehatan Republik Indonesia Nomor 67 Tahun 2016 Tentang Penanggulangan Tuberkulosis, dan beberapa literature terkait mendapatkan 2 tingkatan Tuberkulosis dan 12 data gejala Tuberkulosis pada anak. Aplikasi Si Tubo diharapkan dapat membantu orang tua untuk mendeteksi dini gejala Tuberkulosis pada anak. Aplikasi dapat digunakan sebelum melakukan konsultasi dengan dokter di klinik atau rumah sakit terdekat. Deteksi dini diperlukan agar orang tua bisa melakukan langkah pencegahan, pemeriksaan lebih lanjut dan juga untuk mengantisipasi karena durasi pengobatan yang cukup lama agar anak dapat pulih total dari Tuberkulosis dan terhindar dari komplikasi, selain itu untuk mengurangi jumlah Tuberkulosis di Indonesia yang saat ini menduduki peringkat pertama didunia untuk jumlah penderita Tuberkulosis.

\section{UCAPAN TERIMA KASIH}

Penulis mengucapkan terimakasih kepada rekan-rekan dosen dan mahasiswa di lingkungan Universitas AMIKOM Purwokerto dan juga kepada Lembaga Penelitian Pengabdian Masyarakat Universitas AMIKOM Purwokertoyang membantu selama proses penelitian.

\section{REFERENSI}

[1] M. Indah, “Tuberkulosis," InfoDatin Pusat Data dan Informasi Kementerian Kesehatan RI, Pusat Data dan Informasi Kementerian Kesehatan RI, Jakarta, 2018.

[2] N. W. Sangadji and H. Kusnanto, "Tuberculosis Paru pada Anak di Salatiga: Pengaruh Kondisi Rumah dan Pendapatan Keluarga," Berita Kedoteran Masyarakat, vol. 34, no. 3, pp. 121-126, 2018.

[3] World Health Organization, Global Tuberculosis Report 2015, 20th ed. 2015.

[4] W. Rahardiyanti, "Gambaran Karakteristik Penderita Tuberkulosis pada Anak Umur 1-5 Tahun yang Berobat di Balai Kesehatan Paru Masyarakat Kota Semarang," Jurnal Kesehatan Masyarakat, vol. 1, no. 2, pp. 525-534, 2012.

[5] Z. Ismah and E. Novita, "Studi Karakteristik Pasien Tuberkulosis di Puskesmas Seberang Ulu 1 Palembang," Unnes Journal of Public Health, vol. 6, no. 4, pp. 218-224, 2017.

[6] Kusrini, Aplikasi Sistem Pakar Menentukan Faktor Kepastian Pengguna dengan Metode Kuantifikasi Pertanyaan. Yogyakarta: Andi Offset, 2008.

[7] F. N. Afiana and I. R. Yunita, “Aplikasi ‘GIZIe’ Untuk Mengetahui Status Gizi Balita Menggunakan Metode Forward Chaining," Jurnal RESTI (Rekayasa Sistem dan Teknologi Informasi), vol. 3, no. 2, pp. 297-303, 2019.

[8] A. A. Pramesti, R. Arifudin, and E. Sugiharti, "Expert System for Determination of Type Lenses Glasses Using Forward Chaining Method," Scientific Journal of Informatics, vol. 3, no. 2, pp. 177188, Nov. 2016.

[9] A. Latubessy and A. Jazuli, “Analisis Model Penelusuran Backward Chaining dalam Mendeteksi 
Tingkat Kecanduan Game pada Anak,” Jurnal Teknologi dan Sistem Komputer, vol. 5, no. 4, pp. 129134, Oct. 2017.

[10] S. Iriani, "Penerapan Metode Backward Chaining pada Sistem Pakar Diagnosa Penyakit Tulang Manusia," Indonesian Journal on Networking and Security, vol. 4, no. 1, pp. 51-55, 2015.

[11] N. Mukhtar and S. Samsudin, "Sistem Pakar Diagnosa Dampak Penggunaan Softlens Menggunakan Metode Backward Chaining," Jurnal Buana Informatika, vol. 6, no. 1, pp. 21-30, 2015.

[12] D. Rosmala, "Metode Backward Chaining Untuk Diagnosa Penyebab Stroke Pada Pasien Penderita," Expert: Jurnal Sistem Informasi, vol. 8, no. 2, pp. 49-55, 2017.

[13] Menteri Kesehatan Republik Indonesia, "Peraturan Menteri Kesehatan Republik Indonesia Nomor 67 Tahun 2016 Tentang Penanggulangan Tuberkulosis," 2017.

[14] A. Rupnawar, A. Jagdale, and S. Navsupe, "Study on Forward Chaining and Reverse Chaining in Expert System," International Journal of Advanced Engineering Research and Science, vol. 3, no. 12, pp. 60-62, 2016.

[15] W. D. Prasetyo and R. Wahyudi, "Sistem Pakar Diagnosis Penyakit Ternak Sapi Menggunakan Metode Forward Chaining Berbasis Website Responsif," Jurnal Teknologi dan Terapan Bisnis, vol. 2, no. 1, pp. 13-21, 2019. 
